
anger lawmakers

Revelations about the unauthorized transfer of tissue samples by a US neuroscientist are adding to the challenges faced by researchers who are attempting to set up biobanks stores of human tissues that can be used to probe the causes of disease.

The latest problems stem from the case of Trey Sunderland, chief of the Geriatric Psychiatry Branch of the National Institute for Mental Health. He is accused of shipping more than 3,000 samples of human spinal fluid to the drug company Pfizer without approval from his employers.

A subcommittee of the US "There is nothing House Committee on Energy more corrosive to and Commerce, which is investigating the shipments, said on 13 June that Sunderland received $\$ 285,000$ for the samples. This was part of more than $\$ 600,000$ he received from the company between 1998 and 2004.

Sunderland invoked his right not to testify against himself at a 14 June hearing. His lawyer did not return phone calls seeking comment.

The allegations, which surfaced after a tip-off from a whistleblower in April last year, angered lawmakers. "What we have learned from this investigation is that the National Institutes of Health (NIH) lacks adequate controls for human tissue samples, human subject protection, and the scientific conduct of many of its senior employees," says committee member John Dingell (Democrat, Michigan).

Such criticism worries researchers, because scientists are starting to use stored banks of tissue to link genetic, medical and personal health data. Iceland, Estonia and the United Kingdom are already developing national databases, and the United States is considering setting up a biobank containing information on hundreds of thousands of Americans (see Nature 429, 475-477; 2004). The NIH has already announced two specific projects linking genetic and environmental information on patients with conditions such as Alzheimer's disease.

Ethicists and scientists fear that reports of lax policies and misconduct will hurt such initiatives. "If there is a perception that the researcher is using the samples to line his or her pockets on the side, you're going to lose public support," says Arthur Caplan, an ethicist at the University of Pennsylvania in Philadelphia. ${ }^{\alpha}$ There is nothing more corrosive to altruism than people making money off research."

Scandals elsewhere have already had similar effects. In Britain, for example, scientists reported a drop in the donation of organs for research after a pathologist at Alder Hey Hospital in Liverpool was revealed to have illegally removed organs from the bodies of children on which he had conducted post-mortems (see Nature 409,$655 ; 2001$ ). The incident led to new human-tissue legislation in 2004 and the creation of the Human Tissue Authority, tasked with overseeing the handling of such samples.
Plans to set up human tissue banks have been hit by the alleged sale of s amples to a US drug firm.

In Sunderland's case, a lack of oversight is giving particular cause for concern. "A lot of this stuff was collected with pretty vague consent and rules," says Caplan. "It's an issue and it's going to pop up again." Michael Gottesman, $\mathrm{NIH}$ deputy director for intramural research, says the agency will clarify its policies on the storage and shipment of tissue samples and develop an electronic database for tracking

\title{
Doomsday food store takes pole position
}

\begin{abstract}
There's something fitting about the decision to site a bastion against the end of the world in a place that looks as if it has already experienced the apocalypse. On 19 June, a construction crew started work on a doomsday seed bank from which the genetic riches of Earth's food crops could, if necessary, be reconstituted. The loc ation: the island of Spitsbergen in the Svalbard archipelago, a desolate place where
\end{abstract}

the winters are long and dark, and polar bears outnumber people.

The island's remoteness, say staff at the Global Crop Diversity Trust, a charitable organization bas ed in Rome that has helped develop the bank, makes it the ideal location to store samples safely. Spitsbergen is free of tectonic activity, and its permafrost would preserve seeds at around $-4{ }^{\circ} \mathrm{C}$. Coalfrom a localmine will beused to power refrigeration units that will further cool the bank to the internationally recommended standard of -20 to $-30^{\circ} \mathrm{C}$.

"It's a resource that needs to last for ever," says Cary Fowler, the trust's director. Fowler says that such a bank is needed in case a species becomes extinct or loses genetic variety through overuse. Some of the three million seeds earmarked for storage could be called upon to thwart a new disease or drought, or even extinctions caused by nuclear war. Although others eed banks exist, the trust is developing the Spitsbergen facility because many banks are poorly maintainedand face uncertain futures owing to funding problems. Norway, which administers Svalbard, willfund the US\$3-million construction costs, and the trust will pay for its maintenance, which 


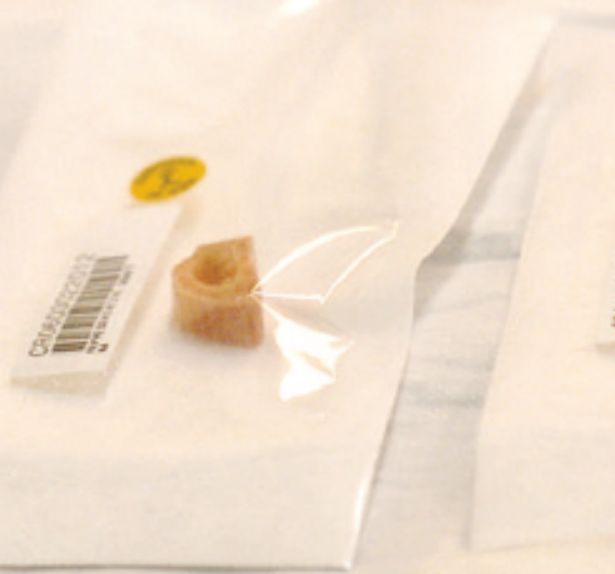

patient samples in all of its 27 branches.

Such measures could help to restore confidence among potential donors. But biobank officials will have to tackle other issues if the initiatives are to succeed, such as questions about who 'owns' the information stored in tissue repositories. In April, for example, a US federal judge had to intervene in a dispute between patients, a researcher and the University of Washington in St Louis over a valuable tissue repository housed at the university (see Nature 440, 1102-1103; 2006).
There are also concerns about how investigators protect the privacy of patients who donate tissue, and how they give consent for future studies on these tissues. National laws differ on such matters, although several efforts are under

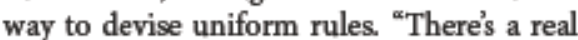
movement for harmonization across international barriers," says Mark Sobel, executive officer of the American Society for Investigative

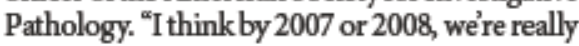
going to see some global acceptance for it." Erika Check
Fowler estimates at around $\$ 100,000$ annually. The trust, which expects the facility to be completed by 2007 , will also help developing countries prepare and transportseeds to the Arctic.

The bank will be carved into one of the island's sandstone mountains, and will consist of a 50-metre tunnelleading to a storage facility reinforced with one-metre-thick concrete. Seeds will be wrapped in aluminium foil to keep out moisture. The cave will be protected by two highsecurity doors armed with motion detectors. No full-time staff will oversee the facility, says Fowler, because it is accessible only by an air-strip about three kilometres away, making it relatively easy to track people's comings and goings.
"It's about providinglongterm security for crop plants," says plant scientist Matthew Daws of the Millennium Seed Bank Project atKew Gardens in London. "It's an insurance policy for countries to dep osit some of their collection and have confidence that after thousands of years their seeds will be viable." Jacqueline Ruttimann
ON THE RECORD

"Life on Earth is at the ever-increasing risk of being wiped out by a disaster such as sudden global warming, nuclear war, a genetically engineered virus or other dangers we have not yet thought of."

Cosmologist Stephen Hawking delivers an upbeat assessment of why humans should colonize space.

Source: AP

\section{SCORECARD}

Dirtyrats Astudy of sewer rats reveals that they have healthier immune systems than their hygienically protected laboratory cousins, leading scientists toponder the medical value of filth.

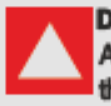

David Beckham

A branding study shows that British children are obsessed with celebrities. Top of the pile is the England football captain, who is more on the kids minds than the toys and clothes marketed at them.

7 Sunscreen US toxicologists find that nanoparticles used in some sunscreens and cosmetics might be able to cause damage to nerve cells, atleast in mice.

\section{OVERHYPED}

\section{Chinese engineers}

Lastautumn, the US National Academiesset off alarm bells in Washington with a report claiming, among other things, that China had produced 600,000 engineering graduates last year to America's 70,000. The numbers were compelling enough to help convince President Bush to endorse a multi-billion-dollar 'competitiveness initiative'.

But this week, the academies quietly revised the China number to 350,000 and the US number to 140,000 . Why? It seems that the original report was com paring apples withoranges. Or in this case, fully fledged US engineers with the Chinese equivalent of car mechanics. 